\title{
Frequency of RBC Alloantibodies in Chinese Surgical Patients
}

\author{
Qiushi Wang Qiaoni Yang Yingzhe Bai Chengxin Zhang Yanni Diao Deqiang Fang
}

Department of Blood Transfusion, Shengjing Hospital, China Medical University, Shenyang, China

\section{Keywords}

Red blood cells · Alloantibody · Surgery

\section{Summary}

Background: The aim of this study was to evaluate the frequency of red blood cell (RBC) alloantibodies in surgical patients. Methods: Blood samples of 18,980 Chinese surgical patients were collected and tested between January 2009 and September 2010. For patients with RBC alloantibodies, sequences of antibodies were identified with the DiaMed Asia antibody screening system. Data regarding sex, age, transfusion history, pregnancy history, and alloantibody specificity were collected. Results: 39 alloantibodies were identified from 18,980 samples, yielding a prevalence of $0.21 \%$. The most frequently identified alloantibodies were Rhesus system antibodies (28/39, 71.8\%), including anti-E (17/39; 1 anti-E accompanied by anti-Fy ${ }^{b}$, anti-c (5/39), anti-cE (2/39), anti- $C^{w}$ (1/39), anti-D (1/39), and anti-e (1/39). Other antibodies included anti-M (5/39), anti-Le ${ }^{a}$ (2/39), anti-Le ${ }^{b}$ (1/39), anti-K+S (1/39), anti-JKa (1/39), and anti-JS ${ }^{a}$ (1/39). The frequency of alloantibodies was greater in females than in males (31 vs. 8). Conclusion: The results show a higher prevalence of RBC alloantibodies in females than in males. Anti-E was the most common alloantibody identified in this Chinese surgical population and was also more frequent in females compared to males.

\author{
Schlüsselwörter \\ Erythrozyten · Alloantikörper · Chirurgie
}

\section{Zusammenfassung}

Hintergrund: Ziel dieser Studie war die Bestimmung der Häufigkeit von Erythrozyten-Alloantikörpern bei chirurgischen Patienten. Methoden: Zwischen Januar 2009 und September 2010 wurden Blutproben von 18980 chirurgisch behandelten chinesischen Patienten entnommen und getestet. Bei Patienten mit Erythrozyten-Alloantikörpern wurden mittels des DiaMed-Asia-Antikörper-Screeningsystems Antikörpersequenzen erstellt. Daten zu Geschlecht, Alter, bisherigen Transfusionen, Schwangerschaftsvorgeschichte und Alloantikörper-Spezifität wurden gesammelt. Ergebnisse: Unter den 18980 Proben wurden 39 Alloantikörper identifiziert (Prävalenz 0,21\%). Die am häufigsten identifizierten Alloantikörper waren Antikörper des Rhesus-Systems (28/39, 71,8\%): unter anderem Anti-E (17/39; ein Anti-E war begleitet von Anti-

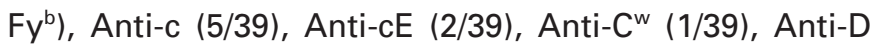
(1/39) und Anti-e (1/39). Des Weiteren wurden Anti-M (5/39), Anti-Le ${ }^{a}$ (2/39), Anti-Le ${ }^{b}$ (1/39), Anti-K+S (1/39), Anti-JK ${ }^{a}$ (1/39) und Anti-JS ${ }^{a}$ (1/39) identifiziert. Alloantikörper traten häufiger bei weiblichen als bei männlichen Patienten auf (31 vs. 8). Schlussfolgerung: Unsere Ergebnisse zeigen eine höhere Prävalenz von ErythrozytenAlloantikörpern bei Frauen verglichen mit Männern. Anti-E war der am häufigsten identifizierte Alloantikörper in der untersuchten chinesischen Population chirurgischer Patienten; auch er fand sich häufiger bei weiblichen als bei männlichen Patienten.

\section{KARGER \\ Fax +497614520714 \\ Information@Karger.de}

www.karger.com
(C) 2012 S. Karger GmbH, Freibur

$1660-3796 / 12 / 0394-0283 \$ 38.00 / 0$

Accessible online at:

www.karger.com/tmh
Dr Qiushi Wang

Shengjing Hospital of China Medical University

36 Sanhao Street, Shenyang, China, 110004

Tel. +86-18940251212, Fax -2423902617

Wangqs18@126.com 


\section{Introduction}

The prevalence of blood type alloantibodies has been reported in a variety of study populations, and varies with the proportion of individuals with a previous history of transfusion or pregnancy. Blood type alloantibodies have been detected in up to $0.8 \%$ of blood donors and on average 1-2\% of hospitalized patients. The prevalence of blood type alloantibodies in patients with a history of blood transfusion is approximately $2-9 \%$. The highest blood type alloantibody rates, ranging from 9 to $30 \%$, have been reported in patients with sickle cell anemia, beta-thalassemia, or hematologic malignancies, who receive chronic transfusion therapy [1-3]. Surgical patients constitute a large group of individuals. However, the blood type alloantibody rate in these patients has not been reported previously. Surgical patients usually present with a unique combination of multiple factors, and the overall impact of these factors on alloantibody production is difficult to predict. For example, many patients will have received previous blood transfusions. However, the blood components and volumes received are unique to each patient and depend on the original disease. The goal of this study was to retrospectively evaluate red blood cell (RBC) alloantibodies in a population of surgical patients of the Shengjing Hospital of China Medical University in order to provide valuable information regarding alloantibody formation prior to surgery, which could guide transfusion practice in the future.

\section{Material and Methods}

\section{Study Population}

18,980 presurgical patients, who underwent blood type and antibody screening prior to surgical intervention at the Shengjing Hospital of China Medical University from January 2009 to September 2010, were included. Gender, age, transfusion history, pregnancy history, and alloantibody specificity were collected. Blood crossmatching was used to choose the blood products. Patient characteristics are shown in table 1.

\section{Serologic Testing}

Alloantibody testing involved a 3-cell screening procedure utilizing low ionic strength saline (LISS) to enhance antigen-antibody interactions. If a patient's serum sample showed agglutination of reagent screening cells at the immediate-spin phase, the $37^{\circ} \mathrm{C}$ phase, or the antiglobulin phase, subsequent alloantibody identification was carried out with an 11-cell panel using LISS. Antibodies were identified using the DiaMed gel system (DiaMed-ID ${ }^{\circledR}$; Bio-Rad Laboratories, DiaMed GmbH, Cressier FR Switzerland). Low ionic strength indirect antiglobulin test kits and screening cells were obtained from Shanghai Blood Medical Biotechnology Inc. (Shanghai, China). The identification cells from DiaMed Asia covered the major blood type antigens. Identification was confirmed by positive homozygous expression of RBC antigens. Antigens were D, C, E, c, e, K, k, Fy ${ }^{\mathrm{a}}, \mathrm{Fy}^{\mathrm{b}}, \mathrm{Jk}^{\mathrm{a}}, \mathrm{Jk}^{\mathrm{b}}, \mathrm{Le}^{\mathrm{a}}, \mathrm{Le}^{\mathrm{b}}, \mathrm{P} 1, \mathrm{M}, \mathrm{N}, \mathrm{S}$, and s. Patients with autoantibodies, antibodies not detected via the screening cells, and positive antibody screens with inconclusive panels were not deemed alloantibody formers $[4,5]$.
Table 1. Patient characteristics

\begin{tabular}{|c|c|}
\hline \multicolumn{2}{|l|}{ Gender } \\
\hline Male & 3,154 \\
\hline Female & 15,826 \\
\hline \multicolumn{2}{|l|}{ Age group, years } \\
\hline$\geq 18$ to $<45$ & 5,493 \\
\hline$\geq 45$ to $<60$ & 10,674 \\
\hline$\geq 60$ to $<70$ & 1,996 \\
\hline$\geq 70$ to $<80$ & 665 \\
\hline$\geq 80$ & 152 \\
\hline \multicolumn{2}{|l|}{ Operation style } \\
\hline Gastrointestinal & 2,031 \\
\hline Urological & 1,155 \\
\hline Respiratory & 416 \\
\hline Gynecologic/obstetric & 12,329 \\
\hline Cardiac & 46 \\
\hline Musculoskeletal & 1,664 \\
\hline Neurological & 693 \\
\hline Liver & 323 \\
\hline Breast & 46 \\
\hline Extremity & 46 \\
\hline Other & 231 \\
\hline \multicolumn{2}{|l|}{ ABO blood group } \\
\hline A & 5,253 \\
\hline B & 5,954 \\
\hline $\mathrm{O}$ & 5,781 \\
\hline $\mathrm{AB}$ & 1,992 \\
\hline \multicolumn{2}{|l|}{$\mathrm{RH}(\mathrm{D})$ group } \\
\hline Negative & 60 \\
\hline Positive & 18,920 \\
\hline
\end{tabular}

\section{Results}

A total of 39 antibodies were identified (table 2). The prevalence of positive antibodies was $0.21 \%$. The most frequently identified alloantibodies were of the Rhesus (RH) system (fig. 1) (71.8\%), including anti-E (17/39), anti-c (5/39), anti-cE (2/39), anti-C (1/39), anti-e (1/39), anti- $C^{w}(1 / 39)$, and anti-D (1/39). Other antibodies were anti-M (5/39), anti-Le ${ }^{\mathrm{a}}(2 / 39)$, anti-Le ${ }^{\mathrm{b}}(1 / 39)$, anti-K+S (1/39), anti-JK ${ }^{\mathrm{a}}(1 / 39)$, and JS ${ }^{\mathrm{a}}$ (1/39).

\section{Discussion}

Alloimmunization to $\mathrm{RBC}$ antigen is an immune response stimulated by repeated transfusion or pregnancy. Previous studies show that about $1-2 \%$ of patients have been exposed to foreign RBCs. The incidence of alloimmunization is much higher in some unique populations, such as those with sickle cell anemia (30-40\%) and thalassemia (9\%). Transfusion and pregnancy history are 2 major causes initiating the formation of alloantibodies [1-3]. Yang et al. [6] reported the alloantibody frequencies in 2 populations of Chinese women (with and without pregnancy history, respectively) to have been 0.178 and $0.111 \%$, respectively $(\mathrm{p}<0.05)$. However, little is 
Table 2. Antibody distribution in 39 cases

\begin{tabular}{|c|c|c|c|c|c|c|c|}
\hline Case & $\begin{array}{l}\text { Age, } \\
\text { years }\end{array}$ & Sex & Diagnosis & $\begin{array}{l}\text { Pregnancy } \\
\text { history }^{\mathrm{a}}\end{array}$ & $\begin{array}{l}\text { Transfusion } \\
\text { history }\end{array}$ & $\begin{array}{l}\text { Transfusion } \\
\text { during } \\
\text { surgery, units }\end{array}$ & $\begin{array}{l}\text { Antibody } \\
\text { identification }\end{array}$ \\
\hline 1 & 37 & $\mathrm{~F}$ & hysteromyoma & $1 / 1$ & 12 years ago & 0 & anti-E(IgG) \\
\hline 2 & 50 & $\mathrm{~F}$ & hysteromyoma, anemia & $2 / 1$ & no & 4 & anti-E(IgG) \\
\hline 3 & 55 & M & cervical spondylosis & - & 1.5 years ago & 4 & anti-E(IgG) \\
\hline 4 & 60 & $\mathrm{~F}$ & cervical spondylosis & $3 / 3$ & no & 0 & anti-E(IgG) \\
\hline 5 & 50 & $\mathrm{~F}$ & hysteromyoma & $2 / 1$ & no & 4 & anti-E(IgG) \\
\hline 6 & 29 & f & endometrial polyp & $1 / 0$ & 4 years ago & 0 & anti-E(IgG) \\
\hline 7 & 48 & $\mathrm{~F}$ & endometrial polyp & $3 / 1$ & 7 years ago & 0 & anti-E(IgG) \\
\hline 8 & 51 & $\mathrm{~F}$ & endometrial carcinoma & $2 / 1$ & 10 years ago & 0 & anti-E(IgG) \\
\hline 9 & 68 & $\mathrm{~F}$ & myocardial infarction, coronary bypass & $3 / 3$ & no & 2 & anti-E(IgG) \\
\hline 10 & 32 & $\mathrm{~F}$ & hysteromyoma & $1 / 1$ & no & 0 & anti-E(IgG) \\
\hline 11 & 61 & M & hepatic cirrhosis, anemia & - & 4 months ago & 7.5 & anti-E(IgG) \\
\hline 12 & 67 & $\mathrm{~F}$ & obstructive jaundice, metastatic ovarian cancer & $3 / 3$ & 2 years ago & 2 & anti-E(IgG) \\
\hline 13 & 58 & $\mathrm{~F}$ & esophageal diverticulum & $1 / 1$ & no & 0 & anti-E(IgM) \\
\hline 14 & 37 & $\mathrm{~F}$ & pregnancy ( 4 pregnancies, 1 birth), thrombocytopenia & $4 / 1$ & no & 6 & anti-E(IgM) \\
\hline 15 & 29 & $\mathrm{~F}$ & extrauterine pregnancy & $2 / 1$ & no & 0 & anti-E(IgM) \\
\hline 16 & 37 & $\mathrm{~F}$ & pregnancy ( 4 pregnancies, 1 birth), thrombocytopenia & $4 / 1$ & no & 4 & anti-E(IgM) \\
\hline 17 & 14 & M & left arm nerve lipoma & - & 1 years ago & 2 & anti-E+c(IgG) \\
\hline 18 & 36 & $\mathrm{~F}$ & Crohn's disease & $1 / 1$ & no & 4 & anti-E+c(IgG) \\
\hline 19 & 80 & M & rectal cancer & - & 7 years ago & 2 & anti-E $+F y^{b}(\operatorname{Ig} G)$ \\
\hline 20 & 42 & $\mathrm{~F}$ & portal hypertension, hepatic cirrhosis & $2 / 1$ & 1 month ago & 2 & anti-C(IgM) \\
\hline 21 & 32 & $\mathrm{~F}$ & incomplete abortion & $3 / 1$ & no & 0 & anti-c(IgG) \\
\hline 22 & 32 & $\mathrm{~F}$ & cervical carcinoma in situ & $2 / 0$ & no & 0 & anti-c(IgG) \\
\hline 23 & 39 & $\mathrm{~F}$ & cervical squamous cell carcinoma & $1 / 1$ & no & 3 & anti-c(IgG) \\
\hline 24 & 26 & $\mathrm{~F}$ & tubal pregnancy & $1 / 1$ & no & 0 & anti-c(IgG) \\
\hline 25 & 36 & $\mathrm{~F}$ & pregnancy ( 3 pregnancies, 1 birth), placenta previa & $3 / 1$ & no & 2 & anti-c(IgM) \\
\hline 26 & 8 & M & autoimmune hemolytic anemia, splenectomy & - & 1 month ago & 2 & anti- $\mathrm{C}^{\mathrm{w}}$ \\
\hline 27 & 51 & M & duodenal obstruction & - & 10 years ago & 16.5 & anti-D(IgG) \\
\hline 28 & 54 & $\mathrm{~F}$ & hepatic cirrhosis, upper gastrointestinal bleeding & $2 / 2$ & 6 months ago & 7 & anti-e(IgG,IgM) \\
\hline 29 & 38 & $\mathrm{~F}$ & hysteromyoma & $5 / 1$ & no & 0 & anti-Le $(\operatorname{IgM})$ \\
\hline 30 & 48 & $\mathrm{~F}$ & hysteromyoma & $4 / 2$ & no & 0 & anti-Le ${ }^{\mathrm{b}}(\operatorname{IgM})$ \\
\hline 31 & 30 & $\mathrm{~F}$ & uterine endometrial carcinoma in situ & - & no & 0 & anti-Le $(\operatorname{IgM})$ \\
\hline 32 & 32 & $\mathrm{~F}$ & pregnancy ( 2 pregnancies, 1 birth), intrauterine death & $2 / 1$ & no & 0 & anti-JK $(\operatorname{IgG})$ \\
\hline 33 & 2 & M & congenital megacolon & - & no & 0 & anti-M(IgM) \\
\hline 34 & 23 & $\mathrm{~F}$ & renal hamartoma & - & no & 0 & anti-M(IgM) \\
\hline 35 & 34 & $\mathrm{~F}$ & extrauterine pregnancy & $2 / 1$ & no & 0 & anti-M(IgM) \\
\hline 36 & 69 & M & cholangiocarcinoma & - & no & 4 & anti-M(IgM) \\
\hline 37 & 35 & $\mathrm{~F}$ & atypical endometrial hyperplasia & $2 / 1$ & no & 0 & anti-M(IgM) \\
\hline 38 & 40 & $\mathrm{~F}$ & hysteromyoma & $3 / 1$ & no & 0 & anti-Js ${ }^{\mathrm{a}}$ \\
\hline 39 & 72 & $\mathrm{~F}$ & cholecystolithiasis and cholelithiasis, choledocholith & $4 / 2$ & 35 years ago & 0 & anti-S, $-\mathrm{K}$ \\
\hline
\end{tabular}

$\mathrm{M}=$ Male; $\mathrm{F}=$ female.

${ }^{a}$ Number of pregnancies/number of births.

known about the frequency in surgical patients. Identification of alloimmunization in surgical patients prior to surgery will facilitate safe transfusion, especially in patients with a transfusion history. Antibody screening is becoming routine in China. Once alloantibodies occur in a patient, an antibody identification test will be recommended. The overall frequency of alloimmunization in our surgical population was $0.21 \%$ which is similar to that previously reported in Chinese blood donors [7]. The frequency of alloimmunization in Chinese patients is overall lower than in other ethnicities. The lower number of pregnancies per woman in China may contribute to the lower frequency of alloantibodies. Also, in Shengjing Hospital in particular, women constitute a much higher proportion of patients than men because of the hospital's prominent Gynecology/Obstetrics Department. In our study, $90.2 \%$ of the female patients had a $\leq 1$ history of pregnancy. In addition, less ethnic variation in our study group (mainly North China) may have contributed to the lower frequency, because RBC antigens are distributed narrowly among people sharing the same ethnicity. It has been reported that patients who received 
Antibody distribution in different sys tem

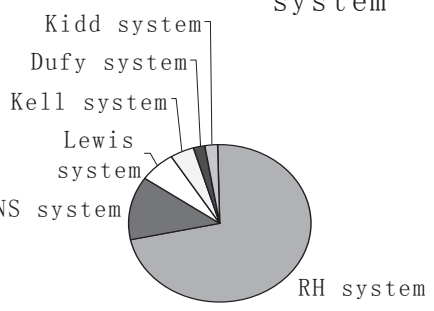

$\square$ RH system $\square$ MNS system $\square$ Lewis system $\square$ Kel1 system $\square$ Dufy system $\square$ Kidd system

Fig. 1. Antibody distribution in different systems.

blood from the same ethnic group (Arab) did not develop alloantibodies, while $27.27 \%$ of patients who received multi-ethnic blood did develop alloantibodies [8].

Although $\mathrm{Rh}(\mathrm{D})$ is the most immunogenic antigen after $\mathrm{A}$ and $\mathrm{B}$, the incidence of anti-D in our population was relatively low (1/39). One reason might be that the D-antigen frequency in the Asian population is generally low (3-5\%). In addition, since 1999, only Rh(D)-negative RBCs have been given to $\mathrm{Rh}(\mathrm{D})$-negative patients in our hospital, which may reduce the chance of developing anti-D antibody. For C-, E-, and c-antigen, frequencies vary greatly between different ethnic groups. In the Caucasian population, $15 \%$ lack the $\mathrm{Rh}(\mathrm{D})$ antigen, 32\% lack the $\mathrm{C}$-antigen, and $71 \%$ lack the E-antigen. In the $\mathrm{Rh}(\mathrm{D})$-positive Caucasian population, $20 \%$ lack the $\mathrm{c}$ antigen and $2 \%$ of the e-antigen [1]. It has been reported that in $\mathrm{Rh}(\mathrm{D})$-positive Northern Chinese the antigen incidence of e, C, c and $\mathrm{E}$ is $92.05,87.8,57.29$ and $49.42 \%$, respectively [9]. In the $\mathrm{Rh}(\mathrm{D})$-negative Northern Chinese population, the antigen incidence of c, e, $\mathrm{C}$ and $\mathrm{E}$ is $95.27,36.26,31.97$ and 9.12\%, respectively [9]. In our study, the most frequent antibodies were anti-E (16/39) and anti-c (5/39). Anti-E can occur as IgG or IgM. In 16 anti-E cases, 12 IgG anti-E (female/male = 10/2) and $4 \mathrm{IgM}$ anti-E (female/male $=4 / 0$ ) were found. Interestingly, among the 14 female anti-E-positive cases, IgG anti-E antibodies were identified in the 10 patients who had a history of either pregnancy $(3 / 10)$ or blood transfusion $(2 / 10)$ or of both $(5 / 10)$. Of the $4 \mathrm{IgM}$ anti-E female cases, 3 were pregnant and 1 had a history of pregnancy 30 years ago. Our data indicate that pregnancy and transfusion are associated with the formation of $\mathrm{IgG}$ antibodies. Further study is necessary to confirm that current pregnancy is associated with the formation of IgM antibody.

The other RH system antibody, IgG anti-c, was found in 4 female patients who all had a history of pregnancy. Anti-D antibody was found in a patient who had a previous history of transfusion (15 years ago); anti- $\mathrm{C}^{\mathrm{w}}$ antibody was found in a patient who had recently received a transfusion (about 45 days ago), and IgM anti-C antibody was found in a woman who had a history of both pregnancy and transfusion. In the alloantibody-positive patients, crossmatch tests were performed. Packed RBCs were subsequently delivered to anti-E-positive patients. Nonetheless, a pregnant woman with a diagnosis of thrombocytopenia (4 pregnancies/1 birth) developed a new anti-c antibody 1 week after transfusion of a compatible unit. In further tests, her RH antigens were shown to be CCDee, while the donor's antigens were CcDee. Had the RH antigen been identified before the transfusion and an RH-compatible unit been transfused, the anti-c antibody may not have formed. We suggest that once anti-E is identified, the RH antigen should be tested and an RH-compatible unit be used.

Besides the antibodies mentioned above, IgM anti-M antibody was found in 5 patients of whom 3 had no previous history of transfusion or pregnancy and 2 had a history of pregnancy.

In summary, alloantibodies were found in this population of Chinese surgical patients. The alloantibody frequency was lower compared to other ethnicities. The majority of antibodies were of the RH system with anti-E occurring most frequently. Sufficient consideration should be given to the possibility of alloantibodies and compatible blood products be prepared in surgical patients prior to surgery to avoid formation of new antibodies.

\section{Disclosure Statement}

The authors declared no conflict of interest.

\section{References}

1 Hamilton JR: Common and frequently encountered antibodies. Transfus Apher Sci 2009;40:189194.

2 Hoeltge GA, Domen RE, Rybicki LA, Schaffer PA: Multiple red cell transfusions and alloimmunization. Experience with 6,996 antibodies detected in a total of 159,262 patients from 1985 to 1993. Arch Pathol Lab Med 1995;119:42-45.

$\checkmark 3$ Winters JL, Pineda AA, Gorden LD, Bryant SC, Melton LJ 3rd, Vamvakas EC, Moore SB: RBC alloantibody specificity and antigen potency in Olmsted County, Minnesota. Transfusion 2001;41: 1413-1420.
4 Walker RH, Lin DT, Hartrick MB: Alloimmunization following blood transfusion. Arch Pathol Lab Med 1989;113:254-261.

5 Spielmann W, Seidl S: Prevalence of irregular red cell antibodies and their significance in blood transfusion and antenatal care. Vox Sang 1974;26:551559.

6 Yang H, Zhao JP: Antibody screened in the female patients with pregnancy history. Chin J Health Lab Technol 2010;20:1450-1451.
7 Zhang W, Zhang JL, Shang JQ, Bai JF: Screening analysis of irregular antibodies of 5,014 blood donors in Hohhot Area. Occupation and Health 2009; 25:1735-1737.

8 Gader AG, Al Ghumlas AK, Al-Momen AK: Transfusion medicine in a developing country alloantibodies to red blood cells in multi-transfused patients in Saudi Arabia. Transfus Apher Sci 2008; 39:199-204.

9 Zhang K, Wang H, Li J: The investigation of distribution of Rh phenotypes in blood donors from Shenyang regions. J Chin Transfusion 2008;21:963-964. 